\title{
"The effect of industrial revolutions on the transformation of social and economic systems"
}

\begin{tabular}{|c|c|}
\hline \multirow{7}{*}{ AUTHORS } & Leonid Melnyk (D) https://orcid.org/0000-0001-7824-0678 \\
\hline & Oleksandr Kubatko (D https://orcid.org/0000-0001-6396-5772 \\
\hline & Iryna Dehtyarova (D https://orcid.org/0000-0003-4615-0437 \\
\hline & R http://www.researcherid.com/rid/C-6783-2019 \\
\hline & Oleksandr Matsenko (D https://orcid.org/0000-0002-1806-2811 \\
\hline & R http://www.researcherid.com/rid/Q-9849-2016 \\
\hline & Oleksandr Rozhko (D https://orcid.org/0000-0001-8415-2084 \\
\hline ARTICLE INFO & $\begin{array}{l}\text { Leonid Melnyk, Oleksandr Kubatko, Iryna Dehtyarova, Oleksandr Matsenko and } \\
\text { Oleksandr Rozhko (2019). The effect of industrial revolutions on the } \\
\text { transformation of social and economic systems. Problems and Perspectives in } \\
\text { Management, 17(4), 381-391. doi:10.21511/ppm.17(4).2019.31 }\end{array}$ \\
\hline DOI & http://dx.doi.org/10.21511/ppm.17(4).2019.31 \\
\hline RELEASED ON & Friday, 27 December 2019 \\
\hline RECEIVED ON & Friday, 11 October 2019 \\
\hline \multirow[t]{2}{*}{ ACCEPTED ON } & Monday, 16 December 2019 \\
\hline & $(\mathrm{cc}) \mathrm{EY}$ \\
\hline LICENSE & $\begin{array}{l}\text { This work is licensed under a Creative Commons Attribution } 4.0 \text { International } \\
\text { License }\end{array}$ \\
\hline JOURNAL & "Problems and Perspectives in Management" \\
\hline ISSN PRINT & $1727-7051$ \\
\hline ISSN ONLINE & $1810-5467$ \\
\hline PUBLISHER & LLC "Consulting Publishing Company "Business Perspectives" \\
\hline FOUNDER & LLC "Consulting Publishing Company "Business Perspectives" \\
\hline
\end{tabular}

NUMBER OF REFERENCES

53
NUMBER OF FIGURES

1
NUMBER OF TABLES

3

(C) The author(s) 2023. This publication is an open access article. 


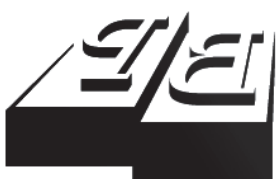

BUSINESS PERSPECTIVES

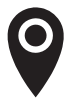

LLC "CPC "Business Perspectives" Hryhorii Skovoroda lane, 10, Sumy, 40022, Ukraine

www.businessperspectives.org

Received on: $11^{\text {th }}$ of October, 2019 Accepted on: $16^{\text {th }}$ of December, 2019

(C) Leonid Melnyk, Oleksandr Kubatko, Iryna Dehtyarova, Oleksandr Matsenko, Oleksandr Rozhko, 2019

Leonid Melnyk, Doctor of Economics, Department of Economics, Entrepreneurship and Business Administration, Sumy State University, Ukraine.

Oleksandr Kubatko, Doctor of Economics, Department of Economics, Entrepreneurship and Business Administration, Sumy State University, Ukraine.

Iryna Dehtyarova, Ph.D., Associate Professor, Department of Economics, Entrepreneurship and Business Administration, Sumy State University, Ukraine.

Oleksandr Matsenko, Ph.D., Associate Professor, Department of Economics, Entrepreneurship and Business Administration, Sumy State University, Ukraine.

Oleksandr Rozhko, Doctor of Economic Sciences, Lecturer, Vice-Rector, Kyiv National Taras Shevchenko University, Kyiv, Ukraine.

\section{(ㄷ)(i)}

This is an Open Access article, distributed under the terms of the Creative Commons Attribution 4.0 International license, which permits unrestricted re-use, distribution, and reproduction in any medium, provided the original work is properly cited.
Leonid Melnyk (Ukraine), Oleksandr Kubatko (Ukraine), Iryna Dehtyarova (Ukraine), Oleksandr Matsenko (Ukraine), Oleksandr Rozhko (Ukraine)

\section{THE EFFECT OF INDUSTRIAL REVOLUTIONS ON THE TRANSFORMATION OF SOCIAL AND ECONOMIC SYSTEMS}

\begin{abstract}
The development of human civilization is related to the constant change of economic formations, and the current social and economic situation is determined by such concepts as Society 5.0, Fourth, and Fifth Industrial Revolutions (FIR, FiIR). The paper aims to estimate the change of human role in each economic formation caused by industrial revolutions. A structured review methodology with a focus on biological, labor, and personal entity of human within the industrial revolutions is used. The description of the changes between the biological, labor, and personality entities of human in various socio-economic formations is discussed. The human as a biological entity is not changed in the first four industrial revolutions, while the FiIR tries to change the biological entity through augmenting the physical capacity. The human as a labor entity is not changed in the first three industrial formations, while the FIR tries to replace the majority of physical human jobs and opens the gate for creative economy and decisions-making. The direct labor participation is minimized within FIR since the economic systems move to the transition to the dominant role of cyber-physical systems. The personal human development is triggered within the FiIR, since informational diversity in economic systems is actualized, and conditions for creative jobs within the creative economy are formed.
\end{abstract}

The biological, labor, and personality entities of human are sequentially actualized within the economic formation caused by industrial revolutions.

\section{Keywords}

Industries 4.0, 5.0, personalization, human development, creative economy, economic transformations, internet of things

\section{JEL Classification L60, P47}

\section{INTRODUCTION}

The humanity is undergoing the complex innovative transformations that provide a phase transition to a new socio-economic formation. These changes gradually lead to three industrial revolutions that affect the dynamics of socio-economic systems. The social phenomena of Third, Fourth and Fifth Industrial Revolutions are radically changing the production basis, lifestyle, and activities of people. Klaus Schwab, the President of the World Economic Forum in Davos, shares the same understanding of social development. Schwab (2017) outlined the dates and content of the previous industrial revolutions. Thus, the First Industrial Revolution (1760-1840) has introduced mechanical production, where the steam engine and the construction of railways sparked it. The Second Industrial Revolution (late nineteenth century - early twentieth century) resulted in the emergence of mass production. It was based on the distribution of electricity and the introduction of the conveyor. The development of computers, including personal computers (PCs), the introduction of semiconductors, the "digital" transition, and the creation of the Internet formed the basis of the 
Third Industrial Revolution (the $1960 \mathrm{~s}$ - the end of the $20^{\text {th }}$ century). The accumulated computational base resulted in the informatization of society and the development of information technologies. The Fourth Industrial Revolution began at the beginning of the new millennium. Schwab (2017) believes that it is aimed at the formation of cyber-physical ("smart" networks) capable of functioning without human participation. Various scientific publications analyze the characteristics of three industrial revolutions, in which humanity currently lives. Rifkin (2013) and Perelet (2014) describe the Third Industrial Revolution as a formation of green economy and harmonize industrial metabolism with the metabolism of the biosphere. Schwab and Davis (2018), Bilan, Rubanov, Vasylieva, and Lyeonov (2019), Schwab (2017) substantiate the need for the Fourth Industrial Revolution, laying the foundation for cyber-physical systems capable of performing production functions independently of humans.

The analysis in these publications is mainly based on the technological aspects of economic transformation. The authors of this article go further, exploring the role and place of human in the implementation of modern industrial revolutions. The paper aims to estimate the change of human role in each economic formation caused by industrial revolutions. Also, the paper investigates the problems that have to be solved in the implementation of each of the industrial revolution.

\section{THEORETICAL BASIS}

Since the beginning of the $21^{\text {st }}$ century, humanity experiences the era of a phase transition to a new socio-economic formation. Its contours are associated with the socio-economic and cultural development strategy of human civilization under the code name "Society 5.0" (Eng. Society 5.0 or Super Smart Society). Denisov (2014) and Cabinet office (2019) assume that such society would use information and information technology in all spheres of life. Keidanren (2017) suggests the following types of socio-economic formations: 1.0: society of hunters and gatherers; 2.0 : agrarian society; 3.0 : industrial society; 4.0 : information-oriented society. It means that during the formation of Society 4.0 with its disruptive innovations the basis for the development of information society has appeared. The invention of computer led to the mass use of personal computers (PCs) and computerization of society. The Internet with remote operation $\mathrm{Wi}$ Fi mode, and digital systems formed the basis for the creation of artificial intelligence, robots, and $3 \mathrm{D}$ printers. Informational changes of governmental financial capacity help to smooth the military conflict results, since it develops the financial products concept based on the idea of the peaceful economy needs (Vyhovska, Polchanov, Frolov, \& Kozmenko, 2018). During the first two decades of 21st century, the world economy faced the appearance of new currencies (including cryptocurrencies) and faced the development of new payment systems, which have drastically changed the current view of business models. For that reason, the financial technologies and their innovations are considered highly valued for startups (Haber, D’yakonova, \& Milchakova, 2018).

The formation of Society 5.0 involves the creation of the internet of things, the active use of artificial intelligence (AI), the tremendous progress of biotechnology, the creation of new materials with unprecedented properties, the leading role of cyber-physical systems, the implementation of the control functions of cloud technologies, etc.

The transition to Society 5.0 happened during the Fourth Industrial Revolution (Industry 4.0) based on the disruptive technologies. Rifkin (2013) as one of the ideologists of the European "green" revolution thinks that the Second Industrial Revolution happened in the late 1980s and early 1990s. The Third Industrial Revolution (TIR), initiated by the EU countries, started in the late 2000s. It is aimed at the solution of global environmental problems and building a green economy. The green economy aims to tremendously reduce the material and energy intensity of socio-economic systems through alternative energy, additive technologies, and horizontal production/consumption systems. Rifkin (2013) formulates the key areas of TIR in the EU: 1) green energy development, 2) the use of infrastructure facilities (in particular, roofs and facades of buildings) for renewable energy installations, 3) the formation of powerful and efficient energy-saving systems, 4) the creation of the in- 
formation and energy system (EnerNet) to control the processes of energy production and distribution; 5) electrification of transport.

To conclude this section, the structured review of recent publications devoted to economic systems transformations under the industrial revolutions is presented in the Table 1 .
A careful analysis of the arguments convinces that the differences in the cited publications characterize not the contradictions between these concepts, but the result of views on various aspects of the phenomena under consideration. The chronological boundaries of events can be considered exclusively conditional, for example, the last decades of the 20th century in

Table 1. The economic systems transformations under the influence of industrial revolutions

\begin{tabular}{|c|c|c|}
\hline Investigators & Focus of the study & Contribution \\
\hline \multicolumn{3}{|c|}{ Industry 4.0} \\
\hline Piccarozzi, Aquilani, and Gatti (2018) & Outline future avenues of Industry 4.0 & $\begin{array}{l}\text { Sustainability issues are relevant at each step of } \\
\text { Industry } 4.0 \text {. Underlines the changes in management } \\
\text { aspects }\end{array}$ \\
\hline $\begin{array}{l}\text { Hayashi, Sasajima, Takayanagi, and } \\
\text { Kanamaru (2017) }\end{array}$ & International Industry 4.0 standards & $\begin{array}{l}\text { International standardization of smart manufacturing } \\
\text { is expected to spread to social life, the living } \\
\text { environment of the general public, leading to the } \\
\text { realization of a smarter society }\end{array}$ \\
\hline Rajnai and Kocsis (2018) & $\begin{array}{l}\text { Enterprise Readiness Assessment for } \\
\text { Industry } 4.0\end{array}$ & $\begin{array}{l}\text { Industry } 4.0 \text { achievements should be actively used by } \\
\text { the management of each business in the direction of } \\
\text { new digital strategies development and digitalization } \\
\text { of company in general }\end{array}$ \\
\hline Fettermann et al. (2019) & $\begin{array}{l}\text { The influence of Industry } 4.0 \\
\text { approaches on operation } \\
\text { management }\end{array}$ & $\begin{array}{l}\text { Industry } 4.0 \text { approaches are most efficient at } \\
\text { technological management and just-in-time } \\
\text { manufacturing }\end{array}$ \\
\hline Oztemel and Gursev (2018) & $\begin{array}{l}\text { Empirical and theoretical research } \\
\text { to develop systematic approach } \\
\text { respective assessments of Industry } \\
4.0\end{array}$ & $\begin{array}{l}\text { Robots, implanted technologies, independent } \\
\text { decision-making, artificial intelligence, 3D printing } \\
\text { creates the core of industrial sector }\end{array}$ \\
\hline Alcácer and Cruz-Machado (2019) & $\begin{array}{l}\text { Industry } 4.0 \text { approaches at } \\
\text { manufacturing environments }\end{array}$ & $\begin{array}{l}\text { Refers to architecture model for Industry } 4.0 \\
\text { subdividing at different levels including asset, } \\
\text { integration, communication and functional }\end{array}$ \\
\hline Halaška and Śperka (2018) & $\begin{array}{l}\text { Use of proper tools in Industry } 4.0 \text { to } \\
\text { maintain efficiency in horizontally and } \\
\text { vertically related business oparations }\end{array}$ & $\begin{array}{l}\text { Technical approaches (process mining) used in } \\
\text { business process management at the operational level } \\
\text { to enhance Industry } 4.0\end{array}$ \\
\hline \multicolumn{3}{|c|}{ Industry 5.0} \\
\hline $\begin{array}{l}\text { Hayashi, Sasajima, Takayanagi, and } \\
\text { Kanamaru (2017) }\end{array}$ & $\begin{array}{l}\text { Standardization of data formats, } \\
\text { models, system for Society } 5.0 \\
\text { architecture, etc. }\end{array}$ & $\begin{array}{l}\text { Overview of international standardization trends } \\
\text { concerning utilization of intelligent devices and } \\
\text { function blocks, their engines, wireless communication } \\
\text { technology, safety and security, energy management } \\
\text { and efficiency for Society } 5.0\end{array}$ \\
\hline Paschek, Mocan, and Draghici (2019) & $\begin{array}{l}\text { Evaluating the business impact of } \\
\text { Industry } 5.0\end{array}$ & $\begin{array}{l}\text { Industry } 5.0 \text { accentuates clear change from mass } \\
\text { automation to the process of enhancing capabilities } \\
\text { of human for achieving personalisation by product } \\
\text { customization to the next level }\end{array}$ \\
\hline Kurzweil (2005) & $\begin{array}{l}\text { Merge of machines and humans } \\
\text { intelligence }\end{array}$ & $\begin{array}{l}\text { Exponential growth of economic system and } \\
\text { accelerating returns }\end{array}$ \\
\hline $\begin{array}{l}\text { Mihardjo, Sasmoko, Alamsyah, and } \\
\text { Elidjen (2019) }\end{array}$ & $\begin{array}{l}\text { Experience-agility innovation model } \\
\text { within Industry } 5.0\end{array}$ & $\begin{array}{l}\text { Customer own experience combined with } \\
\text { organizational agility is considered to promote } \\
\text { competitiveness at Society } 5.0\end{array}$ \\
\hline $\begin{array}{l}\text { Pathak, Pal, Shrivastava, and Ora } \\
\text { (2019) }\end{array}$ & $\begin{array}{l}\text { Core dimensions of integrating human } \\
\text { advanced technology }\end{array}$ & $\begin{array}{l}\text { The Industry } 5.0 \text { is expected to stop the race of robotic } \\
\text { automation }\end{array}$ \\
\hline $\begin{array}{l}\text { Gorodetsky, Larukchin, and Skobelev } \\
(2020)\end{array}$ & $\begin{array}{l}\text { Model of Digital network for } \\
\text { Enterprises of Industry } 5.0\end{array}$ & $\begin{array}{l}\text { The intelligent digital platform for transformation } \\
\text { management of business related to informational } \\
\text { economy and Industry } 5.0\end{array}$ \\
\hline Skobelev and Borovik (2017) & $\begin{array}{l}\text { The convergence of technologies } \\
\text { from internet of things up to } \\
\text { emergent intelligence }\end{array}$ & $\begin{array}{l}\text { Outlining modern technologies - from internet of } \\
\text { things up to artificial intelligence being implemented } \\
\text { to business. The convergence of technics would link } \\
\text { the Industry } 4.0 \text { to Society } 5.0\end{array}$ \\
\hline
\end{tabular}


Renewable energy. Large-scale energy storage. Additive technologies (3D printers). The internet. Digital information systems. The horizontal structure of the organization. Joint economy. Digitalization of social space. Electrification and hydrogenation of transport. Biotechnology (gene modification, hydroponics, 3D printing). Virtualization of the production environment. GPS new materials

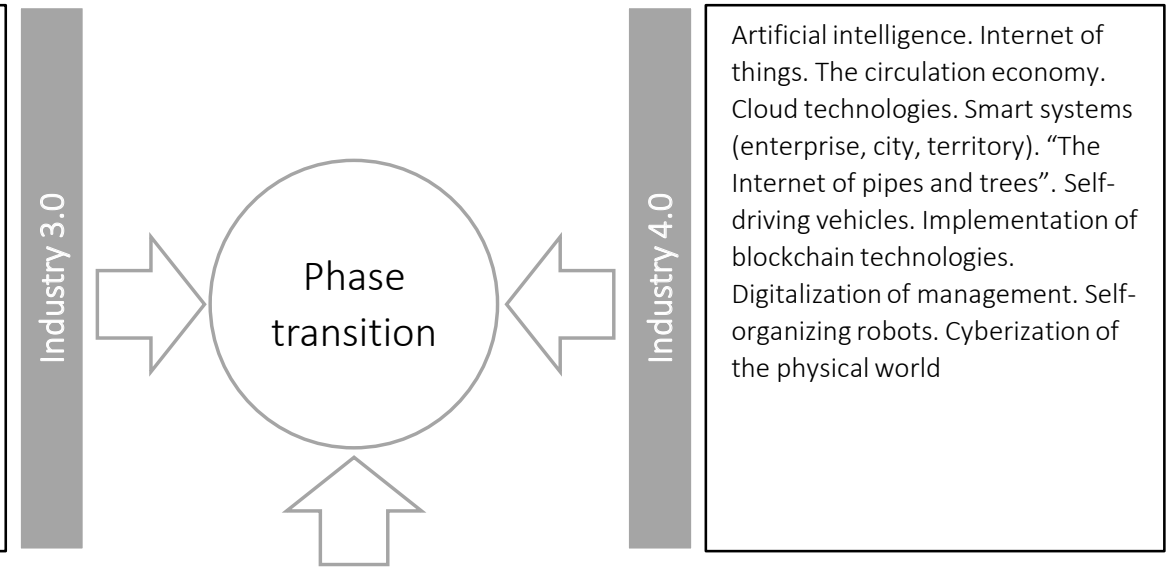

\section{Industry 5.0}

Harmony of the physical, informational and biological spheres. Dialogue of human and artificial intelligence. Individualization of needs. Individualization of human biomonitoring. Individualization of human communication. Cyberization of man. Personalization of production and consumption

Figure 1. The role of industrial revolutions in the implementation of the modern phase transition

one case are called a separate information-oriented phase (Schwab, 2017; Schwab et al., 2018), in another case, Rifkin (2013) includes the same phenomena in the final stage of the Second Industrial Revolution.

We must admit that at present, mankind lives in the era of three industrial revolutions simultaneously. Each of them solves its problems, but together they realize a phase transition to an unprecedented socio-economic formation, as shown in Figure 1.

The above classifications of the transformational shifts of human civilization quite accurately describe the most characteristic features of critical periods in social development. At the same time, a change in the technological basis of the productive forces of society is a predominant feature for classification. Having presented the main concept of industrial revolutions, it is necessary to discuss the transformation of human biological, labor, and social capacity within the main industrial formations.

\section{RESULTS}

A structured review methodology with a focus on biological, labor, and personal entity of human within the industrial revolutions is used to critically select the research papers. Ukrainian philosophers Bobrovskiy (1973) and Bobrovskiy and Melnyk (1992) considered that a humanitarian approach could be based on the idea of the trinity of humans. Bobrovskiy (1973) claimed that each person represents a single system formed by a triad of: "bio," "socio," and "labor." The "bio" basis is formed by the material nature of human and is realized through physiological metabolism. The "socio" basis is an intangible informational source of the personality. The "labor" basis is a person's ability to do work by integrating the "bio" and "socio" bases. The difference in the essential origins of human determines the formation of three different groups of needs, which in many ways are mutually contradictory (see details in Melnyk, 2014). This theory allows presenting the evolutionary trajectory of humans in the light of revolutionary civilization transformations. Thus, the First Industrial 
Revolution gave a start to the physical emancipation of man. Such opportunities appeared with the invention of the machine and its use in the most labor-intensive operations. "Labor" basis showed the best personal qualities. The development of machine production increased the demand for the personal characteristics of "labor" (mental labor, initiative, organizational abilities, etc.). The expansion of machine production also led to an increase in the needs of the personal qualities of workers.

The Second Industrial Revolution marked the formation of the industrial sphere of production in all diversity of its technological and institutional bases. "Black collars," i.e., manual workers, were massively replaced by white-collar workers, i.e., mental workers. However, in production, not only intellectual abilities were needed but also resourcefulness, determination, psychological stability, vision, etc., in other words, a variety of skills. Along with ensuring universal literacy, this gave an impetus to the development of other personal qualities. Industry 2.0 caused total informatization of human needs. Except physiological needs of human "bio", goods with information content for labor and personality bases went into mass production and consumption. In the conditions of the Second Industrial Revolution, personal basis is more clearly manifested and strengthened. Humans become more and more socialized through labor and social communication. In conditions of the Third Industrial Revolution, this quality is further developed. The internet introduced the network forms for further formation of collective (synergetic) qualities of human development a At the same time, Hens, Shkarupa, Karintseva, and Kharchenko (2018) stated that human gradually turns into a network, which can act due to the principle of sustainable development - "think globally - act locally." Mynhardt, Makarenko, and Plastun (2017) analyze the progress, instruments of standardization and regulation of sustainability reporting for better investment decision-making.

In the conditions of Industry 4.0, a person produces less and less physical labor. If earlier a person tried to use robots only for harmful, dangerous and monotonous operations, now the use of machines - cyber-physical systems - in the production is constantly increasing. Melnyk,
Derykolenko, Kubatko, and Matsenko (2019) prove that the internet of things can function without humans. Human is necessary only as a final consumer of goods and services. The educational sphere is considered to be the key driver of successful adaptation to new economic realities. Thus, the ability of high skilled personal production and proper managerial practices promotes national economic development. The same is supported with Oskooii and Ajali (2017), where social capital and entrepreneurs are as important as industrial revolutions. To conclude this section, the structured review of recent publications is devoted to social systems transformations under the industrial revolutions (see Table 2).

It seems that the centuries-old human dream is being realized. Human is being released from physical labor and production functions. Prerequisites are being created for the social development of the personal basis. However, these are just prerequisites. We doubt if a person can completely realize his personal development without participating in the complex tasks of designing the planet's life support systems. Creating the conditions for social progress is a complex social task.

Industry 5.0 is aimed at solving this problem. It is aimed at production and consumption "personalization" (from the English personality). Fifth Industrial Revolution actualizes the information diversity in economic systems, since conditions of creative jobs within the creative economy are formed

The objective necessity of the modern human civilization development is the transition to a new socio-economic formation. The key features of this formation are caused by completely objective circumstances, including the urgent need to reduce the volume of material metabolism of economic systems to the carrying capacity of the planet's ecosystems, i.e., their ability to reproduce the resources and recycle the waste. This task means a radical decrease in the material and energy intensity of economic systems. This can be realized based on a mass transition to alternative (renewable) energy sources and additive technologies of material production using 3D printers (Sineviciene, Sotnyk, \& Kubatko, 2017; Sotnyk, 2016). The report of the International Energy Agency informs that alternative energy projects over the past four years are 
Table 2. The social systems transformations under the influence of industrial revolutions

\begin{tabular}{|c|c|c|}
\hline Investigators & Focus of the study & Contribution \\
\hline \multicolumn{3}{|r|}{ Industry 4.0} \\
\hline Salgues (2018) & $\begin{array}{l}\text { Humanity and industrial } \\
\text { formations }\end{array}$ & $\begin{array}{l}\text { The power of capital replaced by power of intelligence. The knowledge/ } \\
\text { intelligence is a key driver of power }\end{array}$ \\
\hline $\begin{array}{l}\text { Müller, Kiel, and Voigt } \\
(2018)\end{array}$ & $\begin{array}{l}\text { Drivers of Industry } 4.0 \\
\text { implementation }\end{array}$ & $\begin{array}{l}\text { Strategic, operational, ecological, societal challenges are positive } \\
\text { motivators of Industry } 4.0 \text { implementation }\end{array}$ \\
\hline $\begin{array}{l}\text { Zambon, Cecchini, } \\
\text { Egidi, Saporito, and } \\
\text { Colantoni (2019) }\end{array}$ & $\begin{array}{l}\text { Industry } 4.0 \text { relations with } \\
\text { agricultural sector }\end{array}$ & $\begin{array}{l}\text { There are a number of advantages of Industry } 4.0 \text { for large enterprises, } \\
\text { while there are some of them for SMEs }\end{array}$ \\
\hline $\begin{array}{l}\text { Kong, Yang, Huang, } \\
\text { and Luo (2018) }\end{array}$ & $\begin{array}{l}\text { Constructing human-centric } \\
\text { technical framework for } \\
\text { Industry } 4.0\end{array}$ & $\begin{array}{l}\text { Industrial wearable system was developed as a man supporting technic } \\
\text { to fit the operators' necessities to empower human physical, sense and } \\
\text { intellectual capacity within Industry } 4.0 \text {. Industrial wearable system } \\
\text { provides necessity support for workers and incorporates their physical, } \\
\text { sense and intellectual potential in the production system }\end{array}$ \\
\hline $\begin{array}{l}\text { Mikhailov, Rodin, and } \\
\text { Smirnova (2018) }\end{array}$ & $\begin{array}{l}\text { The new system of education } \\
\text { that faces the industry } 4.0 \\
\text { requirements }\end{array}$ & $\begin{array}{l}\text { The paper links the last available theoretical, methodological and practical } \\
\text { knowledge in the realization and activating of human potential at education } \\
\text { within the Industry } 4.0 \text { requirement }\end{array}$ \\
\hline Nagy et al. (2019) & $\begin{array}{l}\text { Safe and efficient Human-Robot } \\
\text { Collaboration }\end{array}$ & $\begin{array}{l}\text { Human-robot collaboration and proper collaborative robots are promoter } \\
\text { of Industry } 4.0 \text { empowering human potential and cognitive skills }\end{array}$ \\
\hline \multicolumn{3}{|r|}{ Industry 5.0} \\
\hline Kurzweil (2005) & $\begin{array}{l}\text { Merge of machines and humans } \\
\text { intelligence }\end{array}$ & $\begin{array}{l}\text { Gradual transformation of humans towards nonbiology through intelligent } \\
\text { orthotics and prostheses }\end{array}$ \\
\hline Salgues (2018) & $\begin{array}{l}\text { Humanity and industrial } \\
\text { formations }\end{array}$ & $\begin{array}{l}\text { Promotion of biomedicine, biodegradable materials. Preserve diversity of } \\
\text { human, animals, plants. The key features are adaptability, agility, mobility }\end{array}$ \\
\hline $\begin{array}{l}\text { Savanevičienè, } \\
\text { Statnickè, and } \\
\text { Vaitkevičiu (2019) }\end{array}$ & $\begin{array}{l}\text { To estimate the individual } \\
\text { innovativeness within Society } \\
5.0\end{array}$ & $\begin{array}{l}\text { The individual innovativeness of Society } 5.0 \text { is described at the generation } \\
\text { levels: Creators (generators of new ideas; Developers (promoting already } \\
\text { existing ideas). Supporters informational influence on developers and } \\
\text { creators to consider potentially harmful consequences }\end{array}$ \\
\hline Nahavandi (2019) & $\begin{array}{l}\text { Concept of Industry } 5.0 \\
\text { involves robots and promotes } \\
\text { collaboration between human } \\
\text { and robots. The human work as } \\
\text { collaborator not as a competitor } \\
\text { with robots }\end{array}$ & $\begin{array}{l}\text { Is expected that Industry } 5.0 \text { would promote new manufacture positions as } \\
\text { Chief Robotics Officer (CRO). A Chief Robotics Officer is a human with deep } \\
\text { of robots and their knowledge interactions with people. The Chief Robotics } \\
\text { Officer is responsible for decision making relating to robots (e.g., what } \\
\text { have to be added/deleted from the production/servicing area to gain best } \\
\text { performance and efficiency }\end{array}$ \\
\hline Onday (2019) & $\begin{array}{l}\text { "Society } 5.0 \text { " as a core idea of } \\
\text { Fifth Industrial Revolution }\end{array}$ & $\begin{array}{l}\text { Within the Industry } 5.0 \text { human and things and are all linked in cyberspace } \\
\text { by artificial intelligence. The final efficiency decisions done by artificial } \\
\text { intelligence are exceeding the human made ones, which creates new } \\
\text { opportunities for industries and society in general }\end{array}$ \\
\hline
\end{tabular}

being implemented faster than planned. Today the share of renewable energy sources in the electric power industry has reached $26 \%$ and can increase up to $30 \%$ by 2024 (Vasylieva, Lyulyov, Bilan, \& Streimikiene, 2019b; Lyeonov, Pimonenko, Bilan, Štreimikiene, \& Mentel, 2019; Yevdokimov, Chygryn, Pimonenko, \& Lyulyov, 2018). In 30 countries, the cost of renewable electricity is equal to the cost of electricity generated by burning fossil fuels. Additive technologies based on 3D - printers demonstrate great opportunities with theoretically material efficiency about $97 \%$. Therefore, the multiple reductions of environmental impact are expected. Additive production methods can reduce the waste compared to subtractive (traditional) methods by $90 \%$ (Telegraf, 2019).

The mentioned changes characterize only the "upper part of the iceberg" of multidimensional phase transition. This is what mankind on the way to a new formation will have to complete. As a result of the implementation of these transformations, the productive forces and production relations should fundamentally change. An integral component of this systemic phenomenon will inevitably result in total informatization ("digitalization") and networking of society. Mishenin, Koblianska, and Mishenina (2015) highlight that it will result in mass automation of production and consumption of "smart" economic goods, transition to horizontal (distributed) interaction between economic agents and the green-led restructuring of supply chains, the formation of a solidary economy, etc. The green economy pays attention to all stages of the product's life: from production to recycling. Especially a lot of questions arise to the stage of recycling solar panels and electronics (Coleman, 
2016), to the organization of a paperless working environment (Tyhulu, Sibande, Zilwa, Langa, Hollis-Turner, \& Bruwer, 2016). It is not by accident that today the future society and the corresponding economic system are called differently, depending on the basic aspect, which a researcher considers as a key classification feature. Some generic names are "post-industrial," "information," "network," "digital society", "knowledge society," "Society 5.0." The upcoming economic system is acquiring a suitable name. It is called "new," "digital," and "information." Such an economy can also be called sustainable, as it ensures the achievement of sustainable development goals.

The inevitable stage in the development of productive forces should be the independence of artificially created cyber-physical systems based on their self-reproduction and self-organization. This is the result of the system integration of the components of social life inspired by the Fourth Industrial Revolution (Industry 4.0). First, we should mention the internet of things, artificial intelligence, robotic systems, "cloud" technologies, nanotechnologies, and additive systems (Table 3).

Such trajectories appear not only as a result of the technical capacities of the scientific progress of production systems. It happens due to the vital need for technical systems development. They reached the limit beyond which a person cannot control the state of their parameters neither in time, nor in space, nor in physical characteristics. Further development of the technosphere created by human is possible only in conditions of self-organization, self-control, and self-repro-

Table 3. Forecast of the most important developments in the internet of things for 2025

Source: Compiled from Schwab (2017), Schwab et al. (2018), Sotnyk et al. (2015), Manyika et al. (2013), Christensen (2016).

\begin{tabular}{|c|c|c|}
\hline \multirow{3}{*}{ Event } & \multicolumn{2}{|c|}{ Important consequences } \\
\hline & Positive & Negative \\
\hline & \multicolumn{2}{|c|}{ Double effect option } \\
\hline \multirow[t]{2}{*}{$\begin{array}{l}\text { The beginning of mobile phone } \\
\text { implementation }\end{array}$} & $\begin{array}{l}\text { Improving the effectiveness of treatment, } \\
\text { personalizing data, monitoring the } \\
\text { location of children }\end{array}$ & $\begin{array}{l}\text { Privacy violation; reduced data security, } \\
\text { addiction }\end{array}$ \\
\hline & \multicolumn{2}{|l|}{ Changes in relationships between people } \\
\hline \multirow{2}{*}{$\begin{array}{l}\text { About } 10 \% \text { of people's clothing is connected } \\
\text { to the Internet }\end{array}$} & $\begin{array}{l}\text { Personalization of clothing; health } \\
\text { monitoring; self-managed treatment }\end{array}$ & Privacy violation; reduced data security \\
\hline & \multicolumn{2}{|l|}{ Real-time identification } \\
\hline \multirow[t]{2}{*}{ One trillion sensors connected to the internet } & $\begin{array}{l}\text { Improving resource efficiency; } \\
\text { productivity growth; improving the } \\
\text { quality of life; environmental monitoring; } \\
\text { improving safety; cheaper services }\end{array}$ & $\begin{array}{l}\text { Breach of confidentiality; job loss for } \\
\text { unskilled workers; increased risk of hacking } \\
\text { and reduced security; increased complexity } \\
\text { and danger of losing control }\end{array}$ \\
\hline & \multicolumn{2}{|c|}{$\begin{array}{l}\text { Changes in business models; the emergence of new and decline of old businesses; } \\
\text { increased use of production and personal assets; automation of information } \\
\text { operations; change of institutions }\end{array}$} \\
\hline \multirow[t]{2}{*}{$\begin{array}{l}\text { Over } 50 \% \text { of home internet traffic is expected } \\
\text { to come directly from devices (neither } \\
\text { entertainment or communication) }\end{array}$} & $\begin{array}{l}\text { Improving the efficiency of the use of } \\
\text { resources and energy; comfort increase; } \\
\text { increased security }\end{array}$ & $\begin{array}{l}\text { Vulnerability to crime and cyber-attacks, } \\
\text { reduced privacy }\end{array}$ \\
\hline & \multicolumn{2}{|c|}{ Increase of distance works; change in the number of jobs } \\
\hline \multirow[t]{2}{*}{$\begin{array}{l}\text { The emergence of the first government, } \\
\text { replacing a significant part of the channels for } \\
\text { obtaining information (for example, census) } \\
\text { with big data sets }\end{array}$} & $\begin{array}{l}\text { An increase in the number of decisions } \\
\text { made in real-time. Improving and } \\
\text { speeding up decision making. An open } \\
\text { information data set for potential } \\
\text { investors. Resource-saving and saving } \\
\text { time. Simplification of procedures for } \\
\text { citizens. The emergence of new jobs }\end{array}$ & $\begin{array}{l}\text { Concern over privacy. Loss of traditional } \\
\text { jobs. Risks of abuse of information } \\
\text { (algorithm) owners. Risks of declining } \\
\text { confidence in the government }\end{array}$ \\
\hline & \multicolumn{2}{|c|}{ Changes in government and business. Changes in information use } \\
\hline \multirow[t]{2}{*}{$\begin{array}{l}10 \% \text { of self-driving electric vehicles on the } \\
\text { roads of leading countries are expected }\end{array}$} & $\begin{array}{l}\text { Reduced stress and road rage. Improved } \\
\text { security. The increasing mobility of old } \\
\text { people and people with disabilities. } \\
\text { Improving electric vehicles and reducing } \\
\text { emissions }\end{array}$ & $\begin{array}{l}\text { Loss of jobs (taxi and truck drivers). Income } \\
\text { loss from traffic tickets. Increased risk of } \\
\text { hacking and cyber-attacks }\end{array}$ \\
\hline & \multicolumn{2}{|l|}{ Change in insurance and emergency assistance } \\
\hline
\end{tabular}


duction of its components. In particular, widespread nanotechnology can be implemented only through the self-organization of computer and processor systems. The same can be said about other components of the future technological environment: the internet of things, the Cloud, smart networks, smart finances, and biotechnology. Schwab and Davis (2018), Skinner (2018), Harari (2018), and Bilan, Rubanov, Vasylieva, and Lyeonov (2019) study this topic and predict such perspectives.

\section{DISCUSSION}

The Fourth Industrial Revolution allows solving a complex of economic, social, and environmental problems. However, humanity faces serious challenges. First, there is the danger that humans could lose control of the development of artificial intelligence and technological cyber-physical systems; second, there is a risk of social (personal) degradation. In conditions of the internet of things, a person does not need to work hard to provide him with the necessary means of subsistence.

Both dangers are inevitable. One of the principles of nonlinear thinking states, if some- thing cannot be prevented, then one must head it. Humanity is following this path, initiating the Fifth Industrial Revolution. The main direction of research is the struggle for the human himself. This goal is transformed into two key tasks: to return a person to the production sphere and personalize the satisfaction of human needs. The solution to the first problem determines the transformation of the production sphere in such a way that a person can maximize her creative potential. Production should require not only certain competencies of the person-manufacturer but also her desire to create in harmony with her inner personal needs.

Personalization of consumption implies a transition from mass production of standard products and services to the satisfaction of everyone's specific individual needs. But this is only one side of the coin. The English word "personalization" means not only the satisfaction of individual demand, although includes it. The current customization process means the individualization of products to the orders of specific consumers. Personalization, however, involves the satisfaction of personal needs, ensuring his/her social development. This is ultimately the leading goal of the sustainable development.

\section{CONCLUSION}

The biological, labor, and personality entities of human are sequentially actualized within the economic formations caused by industrial revolutions. The emergence and development of the last three industrial revolutions is natural due to the logic of social development of human in the specific natural conditions.

The human as a biological entity comes into contradiction with the natural environment during the Second Industrial Revolution and it is only the Third Industrial Revolution, that increases the efficiency of production systems, solving the problems of the global environmental crisis.

The human as a labor entity is overloaded during the first three industrial revolutions and it only the Forth Industrial Revolution, which replace majority of physical human jobs and opens gate for social and solidarity economy. The Fourth Industrial Revolution also creates a global unity of self-governing cyber-physical systems, where the human as a biological entity is not changed.

The human as a personality is overloaded during the first four industrial revolutions, while the Fifth Industrial Revolution creates the opportunities for deeper personalization development. The Fifth Industrial Revolution also tries to change the biological entity through augmenting the physical capacity, which creates definite threats to the human entity in general. 


\section{ACKNOWLEDGMENT}

The publication is funded by research projects "Development of the Fundamental Bases of the Reproductive Mechanism of Socio-Economic Development during the Third Industrial Revolution" (No. 0118U003578) and "Modeling the Eco-Innovations Transfer in the "Enterprise-Region-State" System: Impact on Ukraine's Economic Growth and Security" (No. 0119U100364).

\section{REFERENCES}

1. Alcácer, V., \& Cruz-Machado, V. (2019). Scanning the Industry 4.0: A Literature Review on Technologies for Manufacturing Systems. Engineering Science and Technology an International Journal, 22(3), 899-919. https://doi. org/10.1016/j.jestch.2019.01.006

2. Bilan, Y., Rubanov, P., Vasylieva, T., \& Lyeonov, S. (2019). The Influence of Industry 4.0 on Financial Services: Determinants of Alternative Finance Development. Polish Journal of Management Studies, 19(1), 7093. http://dx.doi.org/10.17512/ pjms.2019.19.1.06

3. Bobrovskiy, P. P. (1973). Mesto $i$ rol evolyutsionnoy idei $v$ biologii (logiko-metodologicheskiy aspekt) [Place and role of evolutionary ideas in biology (logical and methodological aspect)]. Kiev: "Vysshaya shkola". (In Russian). Retrieved from https://ecatalog. univ.kiev.ua/ukr/elcat/new/detail. php3?doc_id=136795

4. Bobrovskiy, P. P., \& Melnyk, L. G. (1992). K triyedinstvu tekushchikh, takticheskikh, strategicheskikh tseley $\mathrm{i}$ interesov [To the trinity of current, tactical, strategic goals and interests]. In O. F. Balatsky (Ed.), Ekologo-ekonomicheskie problemy selskokhozyaystvennogo proizvodstva [Ecological and economic problems of agricultural production] (pp. 102-111). Kiev: "Urozhay". (In Russian).

5. Christensen, C. M. (2016). The Innovators Dilemma. When New Technologies Cause Great Firms to Fail. Harvard: Harvard Business Review Press. Retrieved from https://store.hbr.org/product/theinnovator-s-dilemma-when-newtechnologies-cause-great-firms-tofail/ 5851
6. Coleman, A. (2016). Disposal of obsolete computers framework to reduce environmental effect of disposed computer materials in higher institutions of learning in Africa. Environmental Economics, 7(2), 62-68. https://doi. org/10.21511/ee.07(2).2016.6

7. Denisov, Yu. D. (2014). Analiz yaponskikh prognozov innovatsionnogo razvitiya 1971-2014. [Analysis of Japanese Innovation Development Forecasts 1971-2014]. Assotsiatsiya yaponovedov. (In Russian). Retrieved from http://japanstudies.ru/index.php?option $=$ com content\&task=view\&id $=502$

8. Fettermann, D. C., Cavalcante, C. G. S., Almeida, T. D. de, \& Tortorella, G. L. (2018). How does Industry 4.0 contribute to operations management? Journal of Industrial and Production Engineering, 35(4), 255-268. https://doi.org/10.1080/21681015. 2018.1462863

9. Gorodetsky, V., Larukchin, V., \& Skobelev, P. (2020). Conceptual Model of Digital Platform for Enterprises of Industry 5.0. In I. Kotenko, C. Badic, V. Desnitsky, D. El Baz, \& M. Ivanovic (Eds.), Intelligent Distributed Computing XIII (pp. 35-40). https://doi. org/10.1007/978-3-030-32258-8_4

10. Haber, A. J., D’yakonova, I., \& Milchakova, A. (2018). Estimation of fintech market in Ukraine in terms of global development of financial and banking systems. Public and Municipal Finance, 7(2), 14-23. https://doi.org/10.21511/ pmf.07(2).2018.02

11. Halaška, M., \& Śperka, R. (2018). Process Mining - The Enhancement of Elements of
Industry 4.0. In 4th International Conference on Computer and Information Sciences: Revolutionizing Digital Landscape for Sustainable Smart Society (ICCOINS) (pp. 1-6). Retrieved from https://ieeexplore.ieee.org/ document $/ 8510578$

12. Harari, Yu. N. (2018). 21 Lessons for the $21^{\text {st }}$ Century. London. Jonathan Cape. Retrieved from https://www.penguin. co.uk/books/111/1115346/21 lessons-for-the-21st-century/9781784708283.html

13. Hayashi, H., Sasajima, H., Takayanagi, Y., \& Kanamaru, H. (2017). International Standardization for Smarter Society in the Field of Measurement, Control and Automation. In 56th Annual Conference of the Society of Instrument and Control Engineers of Japan (SICE 2017) (pp. 263266). Retrieved from https://ieeexplore.ieee.org/document/8105723

14. Hens, L., Shkarupa, O. V., Karintseva, O. I., \& Kharchenko, M. O. (2018). Integral assessment of national economy sustainable development. International Journal Environmental Technology and Management, 21(5/6), 306318. https://doi.org/10.1504/ IJETM.2018.100588

15. Keidanren (2017). Revitalizing Japan by Realizing Society 5.0: Action Plan for Creating the Society of the Future. Overview. Retrieved from http://www.keidanren.or.jp/ en/policy/2017/010_overview.pdf

16. Kong, X. T. R., Yang, X., Huang, G. Q., \& Luo, H. (2018). The impact of industrial wearable system on industry 4.0. In 15th IEEE International Conference on 
Networking, Sensing and Control (pp. 1-6). https://doi.org/10.1109/ ICNSC.2018.8361266

17. Kurzweil, R. (2005). The Singularity is Near. New York: Viking Books. Retrieved from http://stargate.inf.elte.hu/ seci/ fun/Kurzweil,\%20Ray\%20-\%20 Singularity\%20Is\%20Near,\%20 The $\% 20 \% 28$ hardback $\% 20$ ed\%29\%20\%5Bv1.3\%5D.pdf

18. Lyeonov, S., Pimonenko, T., Bilan, Y., Štreimikiene, D., \& Mentel, G. (2019). Assessment of green investments' impact on sustainable development: Linking gross domestic product per capita, greenhouse gas emissions and renewable energy. Energies, 12(20). https://doi.org/10.3390/ en12203891

19. Manyika, J., Chui, M., Bughin, J., Dobbs, R., Bisson, P., \& Marrs, A. (2013). Disruptive technologies: Advances that will transform life, business, and the global economy. McKinsey Global Institute. McKinsey \& Company. Retrieved from https://www.mckinsey.com/ business-functions/mckinseydigital/our-insights/disruptivetechnologies

20. Melnyk, L. G. (2014). Trialectics of Systems Formation and Development. Actual Problems of Economics, 10(160), 34-39. Retrieved from http://www. irbis-nbuv.gov.ua/cgi-bin/irbis_nbuv/cgiirbis_64.exe?I21 $\mathrm{DBN}=\mathrm{LINK} \& \mathrm{P} 21 \mathrm{DBN}=\mathrm{UJRN}$ $\& Z 21 \mathrm{ID}=\& S 21 \mathrm{REF}=10 \&$ \&21C $\mathrm{NR}=20 \& S 21 \mathrm{STN}=1 \& \mathrm{~S} 21 \mathrm{FMT}$ $=\mathrm{ASP} \_$meta $\& \mathrm{C} 21 \mathrm{COM}=\mathrm{S} \& 2$ $\mathrm{S} 21 \mathrm{P} 03=\mathrm{FILA}=\& 2$ S21STR=ape_2014_10_5

21. Melnyk, L., Derykolenko, O., Kubatko, O., \& Matsenko, O. (2019). Business models of reproduction cycles for digital economy. In Proceedings of the 15th International Conference on ICT in Education, Research and Industrial Applications. Integration, Harmonization and Knowledge Transfer (pp. 269-276). Kherson, Ukraine. Retrieved from https://essuir.sumdu.edu.ua/ handle/123456789/74617

22. Mihardjo, L., Sasmoko, S., Alamsyah, F., \& Elidjen. (2019).
Boosting the Firm Transformation in Industry 5.0: Experience-Agility Innovation Model. International Journal of Recent Technology and Engineering, 8(2S9), 737-742. http://dx.doi.org/10.35940/ijrte. B1154.0982S919

23. Mikhailov, A. N., Rodin, A. B., \& Smirnova, M. I. (2018). Humanization of Engineering Education in Conditions of the Process of Industry 4.0 Forming. In 4th International Conference on Information Technologies in Engineering Education (pp. 1-4). Retrieved from https://ieeexplore. ieee.org/document/8581805

24. Mishenin, E., Koblianska, I., \& Mishenina, N. (2015). Stratehiia realizatsii ekoloho-oriientovanoho lohistychnoho upravlinnia vyrobnychoiu systemoiu pidpryiemstva [Strategy of implementation of ecologicallyoriented logistical management of enterprise's production system]. Ekonomichnyi Chasopys-XXI Economic Annals-XXI, 3-4(1), 64-67. (In Ukrainian). Retrieved from https://elibrary.ru/item. asp? $\mathrm{id}=23645731$

25. Müller, J. M., Kiel, D., \& Voigt, K. I. (2018). What drives the implementation of Industry 4.0? The role of opportunities and challenges in the context of sustainability. Sustainability, 10(1), 247. https://doi.org/10.3390/ su10010247

26. Mynhardt, H., Makarenko, I., \& Plastun, A. (2017). Standardization of sustainability reporting: rationale for better investment decision-making. Public and Municipal Finance, 6(2), 7-15. https://doi.org/10.21511/ pmf.06(2).2017.01

27. Nagy, B. G., Doka, J., Racz, S., Szabo, G., Pelle, I., Czentye, J., ..., \& Sonkoly, B. (2019). Towards human-robot collaboration: An industry 4.0 VR platform with clouds under the hood. In International Conference on Network Protocols (ICNP) (pp. 4-5). https://doi.org/10.1109/ ICNP.2019.8888107

28. Nahavandi, S. (2019). Industry 5.0-a human-centric solution. Sustainability, 11(16), 4371. https://doi.org/10.3390/ su11164371

29. Onday, O. (2019). Japan's Society 5.0: Going Beyond Industry 4.0. Business and Economics Journal, 10(2), 1-6. Retrieved from https:// www.academia.edu/39149435/ Japan_s_Society_5.0_-_Going_ Beyond_Industry_4

30. Oskooii, N., \& Ajali, J. (2017). Social capital and social entrepreneurship and innovation culture. Innovative Marketing, 13(3), 42-46. http://dx.doi. org/10.21511/im.13(3).2017.05

31. Oztemel, E., \& Gursev, S. (2018). Literature review of Industry 4.0 and related technologies. Journal of Intelligent Manufacturing, 1, 1-56. http://dx.doi.org/10.1007/ s10845-018-1433-8

32. Paschek, D., Mocan, A., \& Draghici, A. (2019). Industry 5.0 - The Expected Impact of Next Industrial Revolution. In Managment Knowledge Learning International Conference (pp. 125132). Retrieved from http://www. toknowpress.net/ISBN/978-9616914-25-3/papers/ML19-017.pdf

33. Pathak, P., Pal, P., Shrivastava, M., \& Ora, P. (2019). Fifth revolution: Applied AI \& human intelligence with cyber physical systems. International Journal of Engineering and Advanced Technology, 8(3), 23-27. Retrieved from https://www.researchgate. net/publication/331966435_Fifth_ revolution_Applied_AI_human_ intelligence_with_cyber_physical_systems

34. Perelet, R. A. (2014). "Zelenaya" ekonomika v YES: Politika $i$ praktika [The "Green" Economy in the EU: Politics and Practice] [MyShared slides]. (In Russian). Retrieved from http://www. myshared.ru/slide/936653/

35. Piccarozzi, M., Aquilani, B., \& Gatti, C. (2018). Industry 4.0 in Management Studies: A Systematic Literature Review. Sustainability, 10, 3821. Retrieved from https://www.mdpi. com/2071-1050/10/10/3821

36. Rajnai, Z., \& Kocsis, I. (2018). Assessing Industry 4.0 Readiness of Enterprises. IEEE 16th World 
Symposium on Applied Machine Intelligence and Informatics (pp. 225-230). https://doi.org/10.1109/ SAMI.2018.8324844

37. Rifkin, J. (2013). The Third Industrial Revolution: How Lateral Power is Transforming Energy, The Economy, and The World. New York: St. Martin’s Griffin Publisher.

38. Salgues, B. (2018). Society 5.0: Industry of the Future, Technologies, Methods and Tools. John Wiley \& Sons, Inc. Retrieved from https://www.wiley.com/en-us/ Society $+5+0 \% 3 \mathrm{~A}+$ Industry $+\mathrm{O}$ $\mathrm{f}+$ the + Future $\% 2 \mathrm{C}+$ Technolog ies $\% 2 \mathrm{C}+$ Methods+and+Tools -p-9781119527633

39. Savanevičienè, A., Statnickè, G., \& Vaitkevičiu, S. (2019). Individual Innovativeness of Different Generations in the Context of the Forthcoming Society 5.0 in Lithuania. Engineering Economics, 30(2). https://doi.org/10.5755/j01. ee.30.2.22760

40. Schwab, K. (2017). The Fourth Industrial Revolution. Davos: World Economic Forum.

41. Schwab, K., \& Davis, N. (2018). Shaping the Fourth Industrial Revolution. Davos: World Economic Forum.

42. Sineviciene, L., Sotnyk, I., \& Kubatko, O. (2017). Determinants of energy efficiency and energy consumption of Eastern Europe post-communist economies. Energy \& Environment, 28(8), 870-884. https://doi. org/10.1177/0958305X17734386

43. Skinner, S. (2018). Digital Human: The Fourth Revolution of Humanity Includes Everyone. Wiley.

44. Skobelev, P. O., \& Borovik, S. Y. (2017). On the Way from Industry 4.0 to Industry 5.0: from digital manufacturing to digital society. International Scientific Journal, 2(6), 307-311. Retrieved from https://stumejournals.com/journals/i4/2017/6/307

45. Cabinet office (n.d.). Society 5.0. Science and Technology Policy. Council for Science. Technology an Innovation. Retrieved from https:// www8.cao.go.jp/cstp/english/society5_0/index.html
46. Sotnyk, I. M. (2016). Energy efficiency of Ukrainian economy: problems and prospects of achievement with the help of ESCOs. Actual Problems of Economics, 1, 192-199. Retrieved from https://essuir.sumdu.edu.ua/ handle/123456789/43448

47. Sotnyk, I. M., Dehtyarova, I. B., \& Kovalenko, Y. V. (2015). Current threats to energy and resource efficient development of Ukrainian economy. Actual Problems of Economics, 11, 137-145. Retrieved from http:// irbis-nbuv.gov.ua/cgi-bin/irbis_nbuv/cgiirbis_64.exe?C21 $\mathrm{COM}=2 \& \mathrm{I} 21 \mathrm{DBN}=\mathrm{UJRN} \& \mathrm{P} 2$ $1 D B N=U J R N \& I M A G E \_F I L E$ DOWNLOAD $=1 \&$ Image_file name $=$ PDF/ape_2015_11_17.pdf

48. Telegraf. Novosti Ukrainy i mira. (2019). Uvelichitsya na 50\%: moshchnost' vozobnovlyaemykh istochnikov, energii vyrastet $v$ techenie 5 let [To increase by 50\%: renewable energy capacity, energy will grow within 5 years]. Retrieved from https://telegraf. com.ua/ekologiya/5202020uvelichitsya-na-50-moshhnostvozobnovlyaemyih-istchnikovenergii-vyirastet-v-techenii-5-let. html

49. Tyhulu, L., Sibande, B., Zilwa, N., Langa, S., Hollis-Turner, S., \& Bruwer, J.-P. (2016). The influence of a paperless office environment on the sustainability of the Master of the High Court in Cape Town. Environmental Economics, 7(3), 33-44. https://doi.org/10.21511/ ee.07(3).2016.04

50. Vasylieva, T., Lyulyov, O., Bilan, Y., \& Streimikiene, D. (2019b). Sustainable economic development and greenhouse gas emissions: The dynamic impact of renewable energy consumption, GDP, and corruption. Energies, 12(17). https://doi.org/10.3390/ en12173289

51. Vyhovska, N., Polchanov, A., Frolov, S., \& Kozmenko, Y. (2018). The effect of it-transformation of the country's financial potential during the postconflict reconstruction. Public and Municipal Finance, 7(3), 15-25. https://doi.org/10.21511/ pmf.07(3).2018.02
52. Yevdokimov, Y., Chygryn, O., Pimonenko, T., \& Lyulyov, O. (2018). Biogas as an alternative energy resource for Ukrainian companies: EU experience. Innovative Marketing, 14(2), 7-15. http://dx.doi.org/10.21511/ im.14(2).2018.01

53. Zambon, I., Cecchini, M., Egidi, G., Saporito, M. G., \& Colantoni, A. (2019). Revolution 4.0: Industry vs. Agriculture in a Future Development for SMEs. Processes, 7, 36. https://doi.org/10.3390/ pr7010036 